\title{
FLT3 Inhibitor
}

National Cancer Institute

\section{Source}

National Cancer Institute. FLT3 Inhibitor. NCI Thesaurus. Code C124800.

Any drug or substance that inhibits the activity of receptor-type tyrosine-protein kinase

FLT3 protein. 